\title{
ГАГАУЗЫ УКРАИНСКОГО БУДЖАКА: НЕИЗВЕСТНОЕ ПРИСУТСТВИЕ
}

\author{
А. В. Шабашов
}

Шабашов А. В. Гагаузи українського Буджака: невідома присутність. У статті розглядається маловідома або зовсім невідома присутність гагаузького етнічного компоненту в українському Буджаці. Автор, спираючись на різні джерела, приходить до висновку, що значна частина гагаузів цього регіону поступово асимілювалася в болгарській та інших етнічних групах.

Ключові слова: гагаузи; болгари; асиміляція; етнічний ареал.

Шабашов А. В. Гагаузы украинского Буджака: неизвестное присутствие. В статье рассматривается присутствие гагаузского этнического компонента в украинском Буджаке, которое малоизвестно или вообще неизвестно. Автор, опираясь на различные источники, приходит к выводу, что значительная часть гагаузов этого региона постепенно ассимилировалась в болгарской и других этнических группах.

Ключевые слова: гагаузы; болгары; ассимиляция; этнический ареал.

Shabashov A. V. Gagauz People of Ukrainian Budzhak: Unknown Presence. The article deals with the presence of the Gagauz ethnic component in Ukrainian Budzhak, which is little known or not known at all. The author, based on various sources, comes to the conclusion that a large part of the Gagauz by that region is gradually assimilated into Bulgarian and other ethnic groups.

Keywords: Gagauz people; Bulgarians; assimilation; ethnic area.

Представители гагаузского народа расселены во многих странах мира, на большинстве континентов ${ }^{1}$. Вне популяционного и этнокультурного ядра гагаузского этноса - Автономно-территориального объединения Гагауз Ери (Гагаузия), входящего в состав Республики Молдова, наиболее многочисленная группа этого народа, которая официально статистически зафиксирована - 31923 человека, проживает на территории Украины². Гагаузы - восемнадцатый по численности народ Украины и составляя, по состоянию на 2001 г., 0,07\% населения страны.

Подавляющее их большинство - 27617 человек - проживает в Одесской области ${ }^{3}$. Ядро этого народа в Украине составляют жители многолюдных моноэтнических или смешанных с болгарами «коренных» сел: Александровка, Виноградовка, Дмитровка, Кубей Болградского, Старые Трояны и Новоселовка Килийского и Котловина Ренийского районов ${ }^{4}$

Однако малоизвестно или практически неизвестно, что их этнокультурное присутствие в южной, украинской части Буджака, другими словами, в юго-западных, заднестровских районах Одесской области, значительно весомее. Существуют только разрозненные упоминания об их проживании здесь и ассимиляции, прежде всего, со стороны болгар. Проблема «неизвестного присутствия» гагаузов в украинском Буджаке была уже косвенно поставлена нами на примере Болградского района.

Целью данного исследования - выявить в диахронии присутствие гагаузского этнического компонента в украинском Буджаке. Сюда не включены вышеупомянутые «коренные» гагаузские и гагаузо-болгарские села, а также относительно незначительное их недавнее расселение во многих населенных пунктах региона, прежде всего в городах, например, около 200 человек в Белгород-Днестровском (0,4\% от всего населения), около 800 человек в Измаиле $(0,9 \%)^{6}$ и т.д.

Анализ имеющихся источников и литературы позволяет выявить два основных анклава «неизвестного присутствия» гагаузов на крайнем Юго-Западе Украины, сформировавшихся при разных обстоятельствах и имеющих разный облик.

Первый включает Тарутинский район, в котором, по переписи населения 1989 г., зафиксировано 2,7 тыс. гагаузов (6\% от всего населения района) $)^{7}$. Появление этой группы обусловлено переселением в 1940 г. (после присоединения Бессарабии к СССР) наиболее 
многочисленного в тот период этнического компонента данного региона - немцев - в Германию ${ }^{8}$. После чего значительная часть этой территории оказалась практически опустевшей.

С другой стороны, много гагаузов после Второй мировой войны было перемещено в восточные регионы СССР, преимущественно в Западную Сибирь. Это имело место в 1945-1946 гг. (трудовая армия) и в 1949 г. («кулаки» и «антисоветские элементы»). Возвращающиеся с конца 1950-х годов на родину «спецпереселенцы» не смогли осесть в родных местах, и многие из них поселились вблизи них, в том числе в малонаселенном Тарутинском районе, непосредственно примыкающем к основному анклаву расселения гагаузов.

Эта страница истории гагаузов и представителей других народов Буджака (которых постигла подобная судьба) пока остается малоизученной. Есть сведения о таком переселении из Сибири в Тарутинский район выходцев из гагаузских сел Гайдарㅇ, Копчак (ТатарКопчак), Дерменджи ${ }^{10}$ и др.

Здесь, опираясь на имеющиеся статистические данные, можем лишь очертить наиболее многочисленные гагаузские общины в Тарутинском районе.

Березино. Население: 3830 чел. $(2001 \text { г. })^{11}$. В 1989 г. гагаузы составляли 28,4\% (639 чел.) от всего населения ${ }^{12}$.

Серпневое (Лейпциг). Население 1836 чел. (2001 г.) $)^{13}$. В 1989 г. гагаузы составляли $9,7 \%$ (431 чел.) от всего населения ${ }^{14}$.

Подгорное (Кульма). Население 1763 чел. (2001 г.) $)^{15}$. Гагаузская община в селе достаточно значительна ${ }^{16}$, однако статистика относительно их количества здесь нам недоступна.

Красное. Население 1376 чел. (2001 г.) $)^{17}$. В 1989 г. из 1429 чел. жителей села 26\% составляли гагаузы ${ }^{18}$.

Вторую, практически неизвестную группу гагаузов, составляют те из них, которые, в основном, были ассимилированы в болгарской, реже - молдавской этнической среде в XIX-XX вв.

Задунайские переселенцы в украинский Буджак сформировали здесь свой анклав в результате двух массовых переселений. Первое относится к периоду русско-турецкой войны 1806-1812 гг. и сразу после нее, второе - к войне 1828-1829 гг. Последнее переселение (1829-1830 гг.) было чисто болгарским; подавляющее большинство принявших участие в нем - выходцы из Юго-Восточной или Средне-Восточной Болгарии. Тогда как переселение 1806-1812 гг. - частично непосредственно из Болгарии (в основном, южные, «вулканештские» гагаузы), и, частично, с молдавских земель, где болгаро-гагаузы проживали на землях местных помещиков еще со второй половины XVIII в. ${ }^{19}$. Именно данные переселенцы и их потомки привнесли значительный гагаузский компонент в современные болгарские по преобладающему этническому составу поселения. Рассмотрим указанные процессы на примере конкретных населенных пунктов, сгруппировав их в три группы географически а также в соответствии с историческими особенностями их заселения и этнодемографических процессов.

Кальчева. Население 3483 (2007 г. $)^{20}$, преобладающее большинство - болгары. В конце 1980-х годов в селе насчитывалось 102 гагауза ${ }^{21}$. Как колония, основана на месте ряда хуторов и животноводческих ферм (кышл) в 1861-1862 гг., в результате массового переселения жителей г. Болград и некоторых других поселений, вызванного репрессиями со стороны молдавских властей, после присоединения Придунавья к Молдавскому княжеству ${ }^{22}$.

Помимо болгар, на северо-западной окраине села поселились гагаузы (гагаузская махала) - представители фамилий Иоржевы, Околаш и др. В двух километрах от окраины села они даже образовали свое отдельное кладбище ${ }^{23}$. Статистика 1907 г. фиксирует в селе большую гагаузскую общину, где проживало 1750 болгар, 625 гагаузов и 20 великорос$\mathrm{cos}^{24}$. Впоследствии гагаузы были ассимилированы болгарским большинством.

Каракурт (Жовтневое). Население 2707 человек $(2001)^{25}$, из них около 50\% назвали родным албанский, а 11,5\% - гагаузский язык. Основано албанцами-арнаутами, переселившимися в 1809-1811 гг. в Буджак из Северо-Восточной Болгарии. Первоначально село располагалось в низовьях р. Большой Ялпуг (территория современной Молдовы), на месте заброшенного ногайского поселения с тем же названием, но до 1816 г. было перенесено на нынешнее место.

Время появления в селе гагаузской общины неизвестно. Вероятно, они, как и болгары, были среди основателей села или появились здесь вскоре после его основания ${ }^{26}$. Эти 
две группы, наряду с преобладающими албанцами, проживали в селе на протяжении всей (или почти всей) его истории. В 1860-1870-х гг. здесь зафиксировано 118 семей албанцев, 14 семей болгар и 20 семей гагаузов ${ }^{27}$, а в 1907 г. числилось 1802 жителя, из которых 1011 албанцев и 481 гагауз $(27 \%)^{28}$. В 1989 г. население села составляло 2789 человек, из них $47 \%$ албанцев и $17,2 \%$ гагаузов ${ }^{29}$. Помимо непосредственного присутствия, гагаузы, благодаря смешанным бракам и межэтническим контактам, оказали значительное воздействие на преобладающее албанское население, в том числе в языке и физическом типе ${ }^{30}$.

Каменка (Ташбунар). Население 3478 (2001 г.) ${ }^{31}$, преобладающее большинство болгары. Однако в прошлом значительную часть населения села составляли гагаузы ${ }^{32}$. В 1860-1870-е гг. в селе зафиксировано 88 болгарских и 50 гагаузских семей ${ }^{33}$. В 1907 г. здесь проживало 1269 болгар и 474 гагауза ${ }^{34}$. Впоследствии гагаузы были ассимилированы болгарским большинством.

Нагорное (Карагач). Население 2611 человек (2001г.) $)^{35}$, преобладающее большинство - болгары. О присутствии здесь в прошлом гагаузов свидетельствует исследовавший их в конце XIX - начале XX в. В. А. Мошков ${ }^{36}$.

Основано в 1811 г. переселенцами из западного и северного Буджака, выходцами из Северо-Восточной Болгарии. В 1860-х годах в село подселились жители окрестных припрутских колонистских сел: Джурджулешты, Анадол (Долинское), Кислица (КислицаПрут), Слободзея и др. ${ }^{37}$. Первоначальный состав населения - болгары и гагаузы. Последние подселялись и из вышеуказанных сел, где также имелось гагаузское население.

Приведем некоторый антропонимический материал, свидетельствующий (как и во многих других выше- и нижеприведенных поселениях) о присутствии здесь гагаузов. В списке «Людей, поселившихся в 1811 году в колонии Карагач», из 26 глав домохозяйств фигурируют: «1. Егоргий Марциовло [здесь и далее - аффикс фамилии: -овло из гаг. оолу «сын» - сын «такого-то»]... 5. Нико Ебанчи [из гаг. йабанджи «чужой; приезжий»]... 7. Егоргий Иордаковло, 8. Карафин Иордаковло... 12. Димитрий Московло, 13. Маноле Киржи [из гаг. кир «грязь» и аффикса пристрастия или профессии -жи /-джи: «любящий грязь» (?)]... 18. Димитрий Куцаровло... 22. Николо Ебанжий [см. № 5]... 25. Егоргий Турузовло» ${ }^{38}$. Впоследствии гагаузы были ассимилированы болгарским большинством.

Болград, районный центр Одесской области, неофициальная столица болгар Буджака, а в прошлом - задунайских колонистов края. Население -17 082 человека $(2001)^{39}$. Основан задунайскими колонистами в 1821 г. на месте старинного поселения Табак (название которого было перенесено на новое поселение, вскоре основанное к северу от Болграда) и назван в честь прародины ${ }^{40}$.

Количество гагаузов, динамику их численности в городе проследить за больший период истории невозможно. Но можно утверждать, что они были среди первопоселенцев, поскольку основанные выселенцами из Болграда Табаки и - позднее - Болгария - были болгаро-гагаузскими селами ${ }^{41}$. Их доля среди жителей города падает после массового переселения болгар в Россию в 1829-1830 гг., представители которого составили в дальнейшем большинство населения города. Жители болгаро-гагаузской туканской махалы (квартала) в значительной степени ассимилировалось в преобладающем этнолингвистическом окружении болгар-ямбольцев и сливенцев. Вместе с тем, гагаузская община города постоянно подпитывалась переселением из близлежащих сел - Виноградовки (Курчу), Кубея (Червоноармейского), Табак, Зализничного (Болгарии) и др.

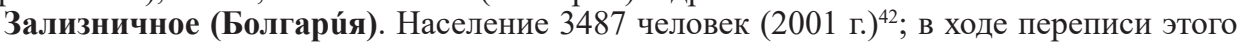
года $76,46 \%$ жителей родным языком признали болгарский, а $4,65 \%$ - гагаузский ${ }^{43}$. Основано в связи с отторжением части Бессарабии, включая центр болгарского водворения г. Болград, от России и переходом ее под юрисдикцию Молдавского княжества. Недовольные ущемлением своих прав, часть болгар и гагаузов отторгнутой территории переходит через границу на российскую сторону, где, в частности, возникает это новое поселение. Датой основания считается $1862 \Gamma^{44}$, хотя процесс формирования поселения начался ранее, а окончательно оно сформировалось позже - в конце 1860 -х годов. Среди основателей села большинство составляли болгары и гагаузы. В 1907 г. из 1645 жителей болгар было 975 человек, гагаузов - 810 человек и 25 - великороссы ${ }^{45}$.

Согласно переписи 1989 г., в селе проживало 2497 человек, из них уже подавляющее большинство числилось как болгары (по сведениям на конец 1980-х годов, - 1525 болгар, 
375 гагаузов, 75 молдаван) $)^{46}$. Таким образом, значительная группа гагаузов ассимилировалась в болгарской этнической среде, но, в свою очередь, оказала влияние на их язык и культуру ${ }^{47}$.

Табаки. Население 2498 человек $(2001 \text { г. })^{48}$. В этом году родным языком в селе назвали: болгарский $-78,18 \%$, гагаузский $-7,61 \%{ }^{49}$. Группа гагаузов поселилась здесь очень рано, вероятно, с самого времени основания села ${ }^{50}$. Сохраняется она, как видим, и до наших дней. Но от Табак вскоре отпочковывается население Болграда, в котором на протяжении последних двух столетий происходят сложные этнодемографические процессы, да и в самих Табаках в значительной степени происходит смена населения. Все же, учитывая ранее происхождение гагаузов в Табаках и подпитку населения этого села в дальнейшем, прежде всего, переселенцами болгарского происхождения, можно предположить, что первоначально приблизительно половину населения этой колонии составляли гагаузы. Это подтверждается данными румынской статистики 1860-1870-х гг., согласно которой здесь проживало 35 семей болгар и 40 семей гагаузов ${ }^{51}$. В 1907 г. в селе насчитывалось 900 болгар и 450 гагаузов ${ }^{52}$. Гагаузы, ассимилированные среди болгар, оказали влияние на язык и культуру последних ${ }^{53}$.

Владычень. Население 1263 чел. (2001) $)^{54}$, из них 74,4\% родным назвали болгарский, $5,3 \%$ - гагаузский язык 55 . Основано переселенцами из Северо-Восточной Болгарии в начале 1810-х гг. на месте поселения турецкого времени Ымпуцита. Время появления здесь гагаузской общины неизвестно, во всяком случае, уже в 1860-1870-х годах здесь числилось 65 семей болгар и 10 семей гагаузов ${ }^{56}$. В 1907 г. в селе насчитывалось 1209 жителей, из них - 1126 болгар, 42 гагауза и 41 молдаванин ${ }^{57}$.

Голица. Население 1506 чел. (2001) $)^{58}$, из них около 92\% назвали родным языком болгарский, и только $0,53 \%$ - гагаузский ${ }^{59}$. Село основано в 1830 г. болгарами - переселенцами из одноименного села на прародине. Данные за 1907 г. свидетельствуют, что помимо 2530 болгар, в селе проживало также 130 гагаузов $^{60}$, вероятно, переселенцев из других сел, впоследствии ассимилированных среди численно преобладающего населения.

Долинское (Анадол). Население 2705 человек (2001) 61 . В настоящее время преобладающий этнос - молдаване ${ }^{62}$. По данным 1848 г., в селе проживало 18 семей (91 человек) болгар [читай - болгар и гагаузов] и 106 семей (512 человек) молдаван ${ }^{63}$. Впоследствии большинство болгар и гагаузов переселилось в соседние болгарские села, вероятно, часть ассимилировалась среди молдаван.

Каланчак (Дермендере). Население 1208 человек (2001) ${ }^{64}$. Преобладающее большинство по переписи 2001 г. - болгары ${ }^{65}$. Однако в 1907 г. в селе зафиксирована значительная группа гагаузов; тогда здесь проживало 625 болгар, 120 гагаузов, 407 малороссов (украинцев) и 53 молдаванина ${ }^{66}$. Вероятно, гагаузы были ассимилированы среди преобладающего населения.

Село основано украинцами в начале XIX в. ${ }^{67}$. С 1830 -х гг., после массового переселения, в том числе в этот населенный пункт, болгар, они становятся здесь преобладающим этносом. Однако в 1860-е годы большинство болгарского населения села переселяется в Приазовье, а на их место подселяются жители Болграда и других поселений ${ }^{68}$. Согласно румынским данным 1860-1870-х гг., в селе имелось 53 семьи болгар и 5 семей гагаузов ${ }^{69}$. Можно предположить, что гагаузы села - переселенцы $1860-$ х годов из Болграда и / или из припрутских сел - Сатунова (Новосельское), Анадола (Долинское) и / или других.

Ларжанка. Население 2386 человек $(2001)^{70}$. Село смешанное по этническому составу, в настоящее время преобладает украинское, русское и молдавское население. Имеются сведения о присутствии в прошлом гагаузов. В. А. Мошков сообщает, что гагаузы здесь проживали смешанно с молдаванами и русскими (вероятно, имеются в виду и великороссы, и малороссы $)^{71}$.

Лощиновка (Кайраклия). Население 1350 человек (2001) 72. В 1989 г. - 1362 человек, из них $69 \%$ болгар ${ }^{73}$. Основано в начале XIX в. в низовьях р. Большой Ялпуг, в районе современного с. Кайраклия (Молдова). В 1821 г. переведено, «по недостатку земли», на современное месторасположение ${ }^{74}$. Позднее вновь была «переоснована», заселена другими людьми и «молдавская» Кайраклия.

В настоящее время в селе гагаузов практически не осталось, но в приазовской Гюневке потомки переселенцев из украинской Кайраклии (1861-1862 гг.) гагаузского происхожде- 
ния были достаточно многочисленны, к ним относятся представители фамилий Златев, Неделков, Ангелов, Ихтияров, Маринов, Костов, хотя в 1950-х гг. только немногие старики помнили гагаузский язык ${ }^{75}$. Гагаузы Кайраклии, видимо, были ассимилированы новой волной болгарских переселенцев 1829-1830 гг. Однако позднее, в 1860-х годах, после выселения большей части кайраклийцев в Приазовье, на их место подселяются болгары и гагаузы из с. Сатунов (Новосельское): «Здесь осталось мало народу. Чтобы село снова увеличить, правительство нашло людей из села Сатунова, и они поселились здесь, чтобы заниматься земледелием» ${ }^{76}$. О присутствии в Сатунове и, соответственно, среди «новых» кайраклийцев гагаузов свидетельствует сообщение о том, что несколько семей болгар и гагаузов все же осталось в Сатунове. Еще в 1950-х годах несколько стариков помнили болгарский и гагаузский языки, хотя молодежь из болгарских и гагаузских семей говорила исключительно по-молдавски и даже в семейном кругу родным языком почти не пользовались ${ }^{77}$.

«Среди населения Кайраклии до сих пор существует деление на кайраклийцев и сатуновцев», - писала в 1950-х годах Е. В. Чешко. Большая часть жителей Лощиновки считает себя потомками сатуновцев - это Бурлаковы, Казаковы, Карачабан, Мариновы, Волковы, Такатлы, Куртевы, Костевы, Моневы, Карапетровы, Ивановы, Урун, Минчевы, Кирковы, Близнак, Калевы. Среди сатуновцев часть составляли гагаузы ${ }^{78}$. В $1860-1870$-е гг. в селе проживала 61 семья болгар, 17 гагаузских и 3 молдавских семьи ${ }^{79}$. В 1907 г. в селе статистика фиксирует уже только болгар, тогда их (и всего населения) здесь насчитывалось 900 человек ${ }^{80}$.

Новосельское (Сатунов). Население 3572 человека $(2001)^{81}$, большинство из которого составляли молдаване ${ }^{82}$. По данным 1848 г., в селе числилось 30 семей (149 человек) болгар [читай - болгар и гагаузов], а всего - 180 семей, 856 человек (подавляющее большинство - молдаване $)^{83}$. Большая часть задунайских колонистов и их потомков выселилась в 1860-х годах, в частности, в с. Кайраклия (Лощиновка). Однако некоторое число семей болгар и гагаузов осталось здесь. Еще в 1950-х годах несколько стариков помнили болгарский и гагаузский языки ${ }^{84}$.

Исходя из вышесказанного, можно прийти к выводу, что юго-западная часть украинского Буджака (современные Болградский, Ренийский и Измаильский районы Одесской области) в начале XIX в. заселялась, помимо менее многочисленных представителей других этносов (молдаван, русских, украинцев, албанцев), болгарами и гагаузами, примерно в равной пропорции. Новое массовое переселение болгар в 1829-1830 гг., переселение болгар, гагаузов и албанцев в 1860-х годах из Придунавья в Приазовье и подселение на их место молдаван (Ренийский район) приводит к тому, что во многих населенных пунктах региона доля гагаузов заметно падает. В последующем большинство из них постепенно ассимилируется в болгарской, в меньшей степени молдавской этнической среде. Тем не менее, этот ареал необходимо включать в этнокультурное пространство Большой Гагаузии, поскольку гагаузы и их ассимилированные потомки внесли свой весомый вклад в формирование данного культурного ландшафта. Другая значительная дисперсная группа гагаузов сформировалась в Тарутинском районе в 1950-х годах в связи с трагическими событиями Второй мировой войны и последующего периода.

${ }^{1}$ Губогло М. Н. Доктринальная основа гагаузской диаспоры // Гагаузы в мире и мир гагаузов. Т. 1. Гагаузы в мире. Комрат-Кишинев: Б/и., 2012. С. 379-392; Первый всемирный конгресс гагаузов. Кишинев: Понтос, 2006. С. 3.

${ }^{2}$ Шабашов А. В. Гагаузы в Украине // Гагаузы в мире и мир гагаузов. Т. 1. Гагаузы в мире. Комрат-Кишинев: Б/и., 2012. С. 413.

${ }^{3}$ Всеукраинская перепись населения 2001 // Государственный комитет статистики Украины. URL: http://2001.ukrcensus.gov.ua/rus/results/general/nationality/ (дата обращения: 26.08.17).

${ }^{4}$ Шабашов А. В. Гагаузы: система терминов родства и происхождение народа. Одесса: Астропринт, 2002. С. 13.

${ }^{5}$ Шабашов А. В. Динамика этнического состава Болградского района Одесской области в XIXXX вв. Заселение района. 1810-1862 гг. // Юго-Запад. Одессика. Историко-краеведческий научный альманах. Вып. 1. Одесса, 2006. С. 174, 176-177, 179-180.

${ }^{6}$ Шабашов А. В. Гагаузы в Украине // Гагаузы в мире и мир гагаузов. Т. 1. Гагаузы в мире. Комрат-Кишинев: Б/и., 2012. С. 414. 
7 Численность и состав населения Одесской области по итогам Всеукраинской переписи населения 2001 года // Государственный комитет статистики Украины. URL: http://2001.ukrcensus.gov.ua/ rus/results/general/nationality/odesa/ (дата обращения: 26.08.17).

${ }^{8}$ Schmidt U. Bessarabien. Deutsche Kolonisten am Schwarzen Meer. Potsdam, 2008. P. 309-332.

9 Грек И. Ф. Село Гайдар: очерки истории и культуры // Лукоморье: археология, этнология, история Северо-Западного Причерноморья. 2011. Вып. 5. С. 204-212, 232.

${ }_{10}^{10}$ Полевые материалы автора.

${ }^{11}$ Березино // Регіони України та їх склад // Верховна Рада України. Офіційний веб-портал. URL: http://w1.c1.rada.gov.ua/pls/z7503/A005?rdat1=06.04.2017\&rf7571=23205 (дата обращения: 26.08.17).

${ }^{12}$ Шабашов A. B. Гагаузы: система терминов родства и происхождение народа. Одесса: Астропринт, 2002. С. 13.

${ }^{13}$ Серпневе // Регіони України та їх склад // Верховна Рада України. Офіційний веб-портал. URL: http://w1.c1.rada.gov.ua/pls/z7503/A005?rdat1=09.04.2017\&rf7571=42497 (дата обращения: 26.08.17).

${ }^{14}$ Шабашов А. В. Гагаузы: система терминов родства и происхождение народа. Одесса: Астропринт, 2002. С. 13.

${ }^{15}$ Підгірне // Регіони України та їх склад // Верховна Рада України. Офіційний веб-портал. URL: http://w1.c1.rada.gov.ua/pls/z7503/A005?rdat1=09.04.2017\&rf7571=23272 (дата обращения: 26.08.17).

${ }^{16}$ Грек И. Ф. Село Гайдар: очерки истории и культуры // Лукоморье: археология, этнология, история Северо-Западного Причерноморья. 2011. Вып. 5. С. 204-212, 232; Полевые материалы автора.

${ }^{17}$ Красне // Регіони України та їх склад // Верховна Рада України. Офіційний веб-портал. URL: http://w1.c1.rada.gov.ua/pls/z7503/A005?rdat1=09.04.2017\&rf7571=23238 (дата обращения: 26.08.17).

${ }^{18}$ Шабашов A. В. Гагаузы: система терминов родства и происхождение народа. Одесса: Астропринт, 2002. С. 13.

${ }^{19}$ Шабашов A. B. К вопросу о переселении болгар и гагаузов в Российскую империю и Бессарабию // България: метрополия и диаспора. Сборник по случай 65-годишнината на д.и.н. Николай Червенков. Кишинев: «SŞB», 2013. С. 109-118.

20 Кальчева // Регіони України та їх склад // Верховна Рада України. Офіційний веб-портал. URL: http://w1.c1.rada.gov.ua/pls/z7503/A005?rdat1=09.04.2017\&rf7571=23962 (дата обращения: 26.08.17).

${ }^{21}$ Шабашов А. В. Гагаузы: система терминов родства и происхождение народа. Одесса: Астропринт, 2002. С. 14.

22 Забытые страницы истории Южной Бессарабии (1856-1861 гг.). Сборник документов и материалов. Кишинев: Б/и., 2012. С. $11-21$.

${ }^{23}$ Топалова С. Из историята на Калчова колония (Бесарабия) // Българска Бессарабия. Вип. 1. Болград, 1999. С. 27-31, 35; Деревенский С. Калчева // Сайт с. Калчева. URL: http://kalcheva.at.ua/ index/0-2 (дата обращения: 26.08.17).

${ }^{24}$ Берг Л. С. Население Бессарабии. Этнографический состав и численность. Пг.: Б/и., 1923. C. 22 .

${ }^{25}$ Каракурт // Регіони України та їх склад // Верховна Рада України. Офіційний веб-портал. URL: http://w1.c1.rada.gov.ua/pls/z7503/A005?rdat1=09.04.2017\&rf7571=53517 (дата обращения: 26.08.17).

${ }^{26}$ Атлас болгарских говоров в СССР. Ч. 1. Вступительные статьи: Комментарии к картам. М.: Изд-во АН СССР, 1958. С. 13.

27 Челак Е. Училищното дело и културно-просветният живот на българските преселенци в Бесарабия (1856-1878). София: Б/и., 1999. С. 41.

28 Берг Л. С. Население Бессарабии. Этнографический состав и численность. Пг.: Б/и., 1923. C. 28.

${ }^{29}$ Шабашов A. В. Гагаузы: система терминов родства и происхождение народа. Одесса: Астропринт, 2002. С. 13.

${ }^{30}$ Шабашов А. В. Система родства албанцев. 2. Система родства албанцев Украины // Записки исторического факультета. Вып. 7. Одесса, 1998. С. 20-25; Шабашов A. В. Гагаузы: система терминов родства и происхождение народа. Одесса: Астропринт, 2002. С. 419-436.

${ }^{31}$ Кам'янка // Регіони України та їх склад // Верховна Рада України. Офіційний веб-портал. URL: http://w1.c1.rada.gov.ua/pls/z7503/A005?rdat1=09.04.2017\&rf7571=24157 (дата обращения: 26.08.17).

32 Полевые материалы автора; Шабашов $A$. В. Ойконимия болгарских населенных пунктов Юга Украины (Одесская, Кировоградская, Николаевская области) // Българска Бесарабия. Вип. 1. Болград, 1999. С. 89; Мошков В. А. Гагаузы Бендерского уезда (Этнографические очерки и материалы). Кишинев: Б/и., 2004. С. 11.

33 Челак Е. Училищното дело и културно-просветният живот на българските преселници в Бесарабия (1856-1878). София: Б/и., 1999. С. 41.

${ }_{34}$ Берг Л. С. Население Бессарабии. Этнографический состав и численность. Пг.: Б/и., 1923.

${ }^{35}$ Нагірне // Регіони України та їх склад // Верховна Рада України. Офіційний веб-портал. URL: http://w1.c1.rada.gov.ua/pls/z7503/A005?rdat1=09.04.2017\&rf7571=22998 (дата обращения: 26.08.17). 
${ }^{36}$ Мошков B. A. Гагаузы Бендерского уезда (Этнографические очерки и материалы). Кишинев: Б/и., 2004. С. 11.

${ }^{37}$ Информация предоставлена Петром Бушняком.

${ }^{38}$ Национальный архив Республики Молдова. Ф. 1. Оп. 1. Д. 3246. Л. 206об. Информация предоставлена Петром Бушняком.

${ }^{39}$ Болград // Регіони України та їх склад // Верховна Рада України. Офіційний веб-портал. URL: http://w1.c1.rada.gov.ua/pls/z7503/A005?rdat1=11.04.2017\&rf7571=23939 (дата обращения: 26.08.17).

${ }^{40}$ Шабашов A. B. Ойконимия болгарских населенных пунктов Юга Украины (Одесская, Кировоградская, Николаевская области) // Българска Бесарабия. Вип. 1. Болград, 1999. С. 69-72.

${ }^{41}$ Мошков B. A. Гагаузы Бендерского уезда (Этнографические очерки и материалы). Кишинев: Б/и., 2004. С. 11.

42 Залізничне // Регіони України та їх склад // Верховна Рада України. Офіційний веб-портал. URL: http://w1.c1.rada.gov.ua/pls/z7503/A005?rdat1=09.04.2017\&rf7571=23960 (дата обращения: 26.08.17).

43 Зализничное (Болградский район). URL: https://ru.wikipedia.org/wiki/\%D0\%97\%D0\%B0\%D0\% BB $\%$ D0 $\%$ B8\%D0\%B7\%D0\%BD $\%$ D0\%B8\%D1\%87\%D0\%BD $\%$ D0 $\%$ BE $\%$ D0 $\%$ B5 $(\% \mathrm{D} 0 \% 91 \% \mathrm{D} 0 \% \mathrm{~B}$ E\%D0\%BB $\%$ D0\%B3\%D1\%80\%D0\%B0\%D0\%B4\%D1\%81\%D0\%BA\%D0\%B8\%D $0 \%$ B $\%$ DD1\%80\% $\mathrm{D} 0 \% \mathrm{~B} 0 \% \mathrm{D} 0 \% \mathrm{~B} 9 \% \mathrm{D} 0 \% \mathrm{BE} \% \mathrm{D} 0 \% \mathrm{BD})$ (дата обращения: 26.08.17).

${ }^{44}$ Грек И., Червенков Н. Българите от Украйна и Молдова. Минало и настояще. София: Издателска къща „Христо Ботев“, 1993. С. 31.

${ }^{4}$ Берг Л. С. Население Бессарабии. Этнографический состав и численность. Пг.: Б/и., 1923. C. 22; Мошков B. A. Гагаузы Бендерского уезда (Этнографические очерки и материалы). Кишинев: Б/и., 2004. С. 11

46 Полевые материалы автора.

${ }^{47}$ Шабашов $A$. В. Опыт сравнительного изучения болгарской и гагаузской систем родства (по материалам Южной Украины) // Этнографическое обозрение. 1995. № 3. С. 90.

${ }^{48}$ Табаки // Регіони України та їх склад // Верховна Рада України. Офіційний веб-портал. URL: http://w1.c1.rada.gov.ua/pls/z7503/A005?rdatl=09.04.2017\&rf7571=23976 (дата обращения: 26.08.17).

49 Табаки (Одесская область). URL: https://ru.wikipedia.org/wiki/\%D0\%A2\%D0\%B0\%D0\%B1 $\%$ D0\%B0\%D0\%BA $\%$ D0\%B8 $(\% \mathrm{D} 0 \% 9 \mathrm{E} \% \mathrm{D} 0 \% \mathrm{~B} 4 \% \mathrm{D} 0 \% \mathrm{~B} 5 \% \mathrm{D} 1 \% 81 \% \mathrm{D} 1 \% 81 \% \mathrm{D} 0 \% \mathrm{BA} \% \mathrm{D} 0 \% \mathrm{~B}$ $0 \% \mathrm{D} 1 \% 8 \mathrm{~F} \% \mathrm{D} 0 \% \mathrm{BE} \% \mathrm{D} 0 \% \mathrm{~B} 1 \% \mathrm{D} 0 \% \mathrm{BB} \% \mathrm{D} 0 \% \mathrm{~B} 0 \% \mathrm{D} 1 \% 81 \% \mathrm{D} 1 \% 82 \% \mathrm{D} 1 \% 8 \mathrm{C}) \quad$ (дата обращения: 26.08.17).

${ }^{50}$ Атлас болгарских говоров в СССР. Ч. 1. Вступительные статьи: Комментарии к картам. М.: Изд-во АН СССР, 1958. С. 13.

51 Челак $E$. Училищното дело и културно-просветният живот на българските преселници в Бесарабия (1856-1878). София: Б/и., 1999. С. 41.

52 Берг Л. С. Население Бессарабии. Этнографический состав и численность. Пг.: Б/и., 1923. C. 23.

${ }^{53}$ Шабашов А. В. Опыт сравнительного изучения болгарской и гагаузской систем родства (по материалам Южной Украины) // Этнографическое обозрение. 1995. № 3. С. 90.

${ }^{54}$ Владичень // Регіони України та їх склад // Верховна Рада України. Офіційний веб-портал. URL: http:/w1.c1.rada.gov.ua/pls/z7503/A005?rdat1=09.04.2017\&rf7571=23949 (дата обращения: 26.08.17).

${ }_{55}$ Владычень (Одесская область). URL: https://ru.wikipedia.org/wiki/\%D0\%92\%D0\%BB\%D0\%B 0\%D0\%B4\%D1\%8B $\%$ D1\%87\%D0\%B5\%D0\%BD $\%$ D1 $\% 8 \mathrm{C}$ (\%D0\%9E $\%$ D0\%B4\%D0\%B5\%D1\%81\% D1\%81\%D0\%BA $\%$ D0\%B0\%D1\%8F \%D0\%BE $\%$ D0\%B1\%D0\%BB $\%$ D0 $\%$ B $0 \%$ D $1 \% 81 \% \mathrm{D} 1 \% 82 \% \mathrm{D} 1$ \%8C) (дата обращения: 26.08.17).

56 Челак E. Училищното дело и културно-просветният живот на българските преселници в Бесарабия (1856-1878). София: Б/и., 1999. С. 41.

${ }^{57}$ Берг Л. С. Население Бессарабии. Этнографический состав и численность. Пг.: Б/и., 1923. C. 23.

58 Голиця // Регіони України та їх склад // Верховна Рада України. Офіційний веб-портал. URL: http://w1.c1.rada.gov.ua/pls/z7503/A005?rdatl=09.04.2017\&rf7571=23951 (дата обращения: 26.08.17).

${ }^{59}$ Голица (Одесская область). URL: https://ru.wikipedia.org/wiki/\%D0\%93\%D0\%BE\%D0\%BB\%D $0 \% \mathrm{~B} 8 \% \mathrm{D} 1 \% 86 \% \mathrm{D} 0 \% \mathrm{~B} 0 \quad(\% \mathrm{D} 0 \% 9 \mathrm{E} \% \mathrm{D} 0 \% \mathrm{~B} 4 \% \mathrm{D} 0 \% \mathrm{~B} 5 \% \mathrm{D} 1 \% 81 \% \mathrm{D} 1 \% 81 \% \mathrm{D} 0 \% \mathrm{BA} \% \mathrm{D} 0 \% \mathrm{~B} 0 \% \mathrm{D} 1 \%$ $8 \mathrm{~F} \% \mathrm{D} 0 \% \mathrm{BE} \% \mathrm{D} 0 \% \mathrm{~B} 1 \% \overline{\mathrm{D}} 0 \% \mathrm{BB} \% \mathrm{D} 0 \% \mathrm{~B} 0 \% \mathrm{D} 1 \% 81 \% \mathrm{D} 1 \% 82 \% \mathrm{D} 1 \% 8 \mathrm{C}$ ) (дата обращения: 26.08.17).

${ }^{60}$ Берг Л. С. Население Бессарабии. Этнографический состав и численность. Пг.: Б/и., 1923. C. 22 .

${ }^{61}$ Долинське // Регіони України та їх склад // Верховна Рада України. Офіційний веб-портал. URL: http://w1.c1.rada.gov.ua/pls/z7503/A005?rdat1=09.04.2017\&rf7571=22992 (дата обращения: 26.08.17)

${ }^{62}$ Итоги Всесоюзной переписи населения 1989 года. Состав населения сельских населенных пунктов Одесской области по численно преобладающей национальности // Статистический сборник. Т. 9. Одесса, 1992. 

C. 71

${ }^{63}$ Скальковский А. А. Болгарские колонии в Бессарабии и Новороссийском крае. Одесса, 1848.

${ }^{64}$ Каланчак (Одесская область) URL: https://ru.wikipedia.org/wiki/\%D0\%9A\%D0\%B0\%D0\%BB\% D0\%B0\%D0\%BD $\%$ D1 $\% 87 \%$ D0 $\%$ B0\%D0\%BA_(\%D0\%9E $\%$ D0\%B4\%D0\%B5\%D1\%81\%D1\%81\%D $0 \% \mathrm{BA} \% \mathrm{D} 0 \% \mathrm{~B} 0 \% \mathrm{D} 1 \% 8 \mathrm{~F}{ }_{0} \mathrm{D} 0 \% \mathrm{BE} \% \mathrm{D} 0 \% \mathrm{~B} 1 \% \mathrm{D} 0 \% \mathrm{BB} \% \mathrm{D} 0 \% \mathrm{~B} 0 \% \mathrm{D} 1 \% 81 \% \mathrm{D} 1 \% 82 \% \mathrm{D} 1 \% 8 \mathrm{C}$ ) (дата обращения: 26.08.17).

65 Там же.

${ }^{66}$ Берг Л. С. Население Бессарабии. Этнографический состав и численность. Пг.: Б/и., 1923. C. 34 .

${ }^{67}$ Кушнір В. Г. Українське населення Буджака за даними Ізмаїльського архіву // Лукомор'я: apхеологія, етнологія, історія Північно-Західного Причорномор'я. Вип. 1. Одесса, 2007. С. 68.

${ }^{68}$ Шабашов А. В. Ойконимия болгарских населенных пунктов Юга Украины (Одесская, Кировоградская, Николаевская области) // Българска Бесарабия. Вип. 1. Болград, 1999. С. 86.

69 Челак E. Училищното дело и културно-просветният живот на българските преселници в Бесарабия (1856-1878). София: Б/и., 1999. С. 41.

70 Ларжанка // Регіони України та їх склад / Верховна Рада України. Офіційний веб-портал. URL: http://w1.c1.rada.gov.ua/pls/z7503/A005?rdat1=09.04.2017\&rf7571=24166 (дата обращения: 26.08.17).

${ }_{71}$ Мошков В. А. Гагаузы Бендерского уезда (Этнографические очерки и материалы). Кишинев: Б/и., 2004. С. 11.

72 Лощинівка // Регіони України та їх склад / Верховна Рада України. Офіційний веб-портал. URL: http://w1.c1.rada.gov.ua/pls/z7503/A005?rdat1=09.04.2017\&rf7571=24168 (дата обращения: 26.08.17).

${ }^{73}$ Полевые материалы автора.

74 Статистическое описание Бессарабии, собственно так называемой, или Буджака, с приложением генерального плана сего края, составленное при гражданской съемке Бессарабии, производившейся по высочайшему повелению размежевания земель оной на участки, с 1822 по 1828 гг. Аккерман, 1899. С. 408-409.

${ }_{75}$ Чешко E. B. К истории кайраклийского говора (Болгарский говор села Лощиновки Болградского района Измаильской области УССР) // Статьи и материалы по болгарской диалектологии СССР. Вып. 2. М., 1952. С. 46.

${ }^{76}$ Там же. С. 24.

77 Там же. С. 60.

78 Там же. С. 25-26, 45.

79 Челак Е. Училищното дело и културно-просветният живот на българските преселници в Бесарабия (1856-1878). София: Б/и., 1999. С. 41.

${ }^{80}$ Берг Л. С. Население Бессарабии. Этнографический состав и численность. Пг.: Б/и., 1923. C. 23.

${ }^{81}$ Новосільське // Регіони України та їх склад // Верховна Рада України. Офіційний веб-портал. URL: http://w1.c1.rada.gov.ua/pls/z7503/A005?rdat1=09.04.2017\&rf7571=23000 (дата обращения: 26.08.17).

82 Итоги Всесоюзной переписи населения 1989 года. Состав населения сельских населенных пунктов Одесской области по численно преобладающей национальности // Статистический сборник. Т. 9. Одесса, 1992.

${ }^{83}$ Скальковский А. А. Болгарские колонии в Бессарабии и Новороссийском крае. Одесса, 1848.

84 Чешко E. В. К истории кайраклийского говора (Болгарский говор села Лощиновки Болградского района Измаильской области УССР) // Статьи и материалы по болгарской диалектологии СССР. Вып. 2. М., 1952. С. 25-26, 45-46, 60. 